\title{
Pendidikan Ramah Anak: Studi Kasus SDIT Nur Hidayah Surakarta
}

\author{
Agus Yulianto \\ SD IT Insan Cendekia, Teras, Boyolali \\ e-mail:yuliagusyulianto@gmail.com
}

\begin{abstract}
Child-friendly education model will create students who not only intellectually intelligent but also spiritually intelligent. Unfortunately, theschool has not been a child-friendly environment. Students often experience bully from their friends or abuse from their teachers or another party in school. The objective of this research is to describe the implementation of child-friendly education on students of Class VB SDIT Nur Hidayah Surakarta. This research was conducted by aqualitative descriptive method with a case study approach. The subject of the study were teachers and students of that class. While other teachers, staffs, securities, and headmaster were the informant. Data was collected by observation, interview, and documentation; applying data and method triangulation. Data was analyzed using interactive analysis model. In achild-friendy education environment, students are treated as the object of education but as the subject instead. They are free to learn and to create under conducive environment. Child-friendly education in SDIT Nur Hidayah Surakarta includes: physically friendly, nonphysically-friendly, in-class learning, and out-class learning.
\end{abstract}

Keywords: Education, child-friendlyeducation, child-friendly environment. 


\section{Pendahuluan}

Pendidikan memiliki posisi yang sangat strategis dalam mencetak generasi masa depan yang berkualitas, memiliki keimanan yang kokoh, kepribadian yang unggul, menguasai sains dan teknologi yang mampu mengarahkan masa depan suatu Negara menjadi lebih maju. Dalam lintasan sejarah umat manusia, hampir tidak ada kelompok manusia yang tidak menggunakan pendidikan sebagai alat pembudayaan dan peningkatan kualitasnya. Pendidikan dibutuhkan untuk menyiapakan anak manusia demi menunjang perannya dimasa datang dan untuk meningkatkan harkat dan martabat manusia yang berlangsung sepanjang hayat.

Dengan demikian pendidikan yang berhasil akan mampu melahirkan manusia yang memiliki kepribadian unggul yang merupakan manifestasi dari pemahaman dan keyakinan aqidah Islam. Akan tetapi, di eraglobalisasi saat ini sering terjadinya kekerasan terhadap anak. Hal ini ditandai dengan munculnya berbagai macam kasus kekerasan yang merebak dalam dunia pendidikan, kasus pelecehan kekerasan seksual terhadap peserta didik, yang merupakan potret buram dari rendahnya produk pendidikan di Indonesia.

Hal ini bukanlah menjadi suatu hal yang baru lagi apabila banyak kalangan yang menilai jika pendidikan yang berlangsung selama ini masih jauh dari nilai-nilai demokratis dan humanisme. Bahkan, dapat dikatakan jika pendidikan secara tidak disadari telah mengalami proses de-humanisasi dan de-demokrasi. Dikatakan demikian karena pendidikan telah mengalami proses kemunduran dengan terkikisnya nilai-nilai kemanusiaan dan demokrasi yang dikandungnya (Haryanto Al Fandi, 2011:203).

Sementara itu, Komisi Perlindungan Anak Indonesia (KPAI) mencatat tahun 2012 kemarin terjadi peningkatan kasus kekerasan terhadap anak di sekolah hingga lebih dari 10 persen. Wakil Komisi Perlindungan Anak Indonesia (KPAI) Apong Herlina mengatakan kekerasan terhadap anak di lingkungan sekolah terjadi dalam berbagai jenis baik itu dilakukan oleh guru maupun antar siswa. Kasus kekerasan itu juga terjadi merata hampir di seluruh wilayah di Indonesia. Catatan ini didasarkan pada hasil survey KPAI di 9 propinsi terhadap lebih dari 1000 orang siswa siswi. Baik dari tingkat Sekolah Dasar/MI, SMP/MTs, maupun SMA/MA. Survey ini 
menunjukan 87,6 persen siswa mengaku mengalami tindak kekerasan. Baik kekerasan fisik maupun psikis, seperti dijewer, dipukul, dibentak, dihina, diberi stigma negatif hingga dilukai dengan benda tajam. Sebaliknya 78,3 persen anak juga mengaku pernah melakukan tindak kekerasan dari bentuk yang ringan sampai yang berat (Fauzulandim, 2012).

Selain itu, kasus kekerasan yang terjadi selama kurun waktu tahun 2013 Komisi Nasional Perlindungan Anak (Komnas PA) melaporkan sebanyak 3.023 kasus pelanggaran hak anak terjadi di Indonesia dan 58 persen atau 1.620 anak jadi korban kejahatan seksual. Dilihat dari klasifikasi usia, dari 3.023 kasus tersebut, sebanyak 1.291 kasus (45 persen) terjadi pada anak berusia 13 hingga 17 tahun, korban berusia 6 hingga 12 tahun sebanyak 757 kasus (26 persen), dan usia 0 hingga 5 tahun sebanyak 849 kasus atau 29 persen (kompas).

Merujuk pada hasil riset dari KPAI tersebut menunjukkan bahwa sekolah hingga detik ini belum bisa menjadi tempat yang ramah bagi anak (siswa). Meskipun disebut sebagai lembaga pendidikan, akan tetapi kekerasan justru sering lahir dari tempat ini. Hal tersebut tentu sangat kontraproduktif dengan makna sekolah itu sendiri, yaitu sebagai tempat untuk belajar, bukan tempat untuk melakukan kekerasan. Sekolah yang seharusnya menjadi tempat begitu menyenangkan bagi anak, karena di lembaga pendidikan inilah anak-anak akan di didik untuk saling mengenal, menyayangi satu dengan yang lain bukan untuk bermusuhan atau saling menindas.

Sekolah seharusnya dijadikan sebagai tempat untuk menanamkan nilainilai akhlakul karimah (pendidikan budi pekerti) dan juga untuk menanamkan nilainilai karakter, telah dinodai oleh perbuatan-perbuatan yang tidak bertangungjawab dan tidak memahami arti dari sebuah proses pendidikan.Pendidikan yang seharusnya menanamkan nilai-nilai kemanusiaan justru melunturkan makna humanisme itu sendiri. Pendidikan yang semestinya menanamkan sikap toleransi, kepedulian terhadap sesama, kesadaran tentang perbedaan (pluralisme), adanya kesamaan hak serta kewajiban, kebebasan berpendapat dan sebagainya, justru mengebiri makna kebebasan dan memasung kemerdekaan peserta didik. Akibatnya, apresiasi output pendidikan terhadap keagungan nilai humanistik, demokrasi, keluhuran budi, dan 
hati nurani menjadi nihil (Haryanto Al Fandi, 2011:203). Dalam hal ini bukan hanya sekolah sebagai institusi pendidikan yang namanya akan tercemar, kepala sekolah, guru, siswa bahkan orang tua pelaku juga akan menjadi jelek di mata masyarakat. Kekerasan di sekolah atas nama apapun seharusnya tidak terjadi.

Menurut Bashori Muchsin (2010:51-54), untuk mensikapi kondisi tersebut maka diperlukan adanya perlindungan terhadap hak-hak anak. Hak anak ini sudah tercantum dalam suatu Konvensi Hak Anak tahun 1989 yang disepakati dalam sidang Majelis Umum PBB ke 44, yang selanjutnya dituangkan dalam resolusi PBB Nomor 44/25 tanggal 5 Desember 1989. Dimana setiap anak tanpa memandang ras, jenis kelamin, asal-ususl keturunan, agama maupun bahasa, mempunyai hak-hak yang mencakup 4 bidang yaitu: Hak Hidup, Hak Mendapatkan Perlindungan, Hak untuk Tumbuh Kembang, dan Hak Partisipasi.

Berdasarkan hal tersebut, pada tahun 2002 Indonesia menetapkan suatu peraturan perundang-undangan No. 23 tahun 2002 tentang perlindungan anak, yang dijelaskan dalam Pasal 4, yang berbunyi "Setiap anak berhak untuk hidup, tumbuh, berkembang dan berpartisipasi secara wajar sesuai dengan harkat dan martabat kemanusian, serta mendapat perlindungan dari kekerasan dan diskriminasi”. Tujuan dari undang-undang tersebut sebagai suatu upaya agar hak-hak anak bisa benar-benar ditegakkan dan dihargai oleh semua orang. Karena anak merupakan tunas, potensi, dan generasi penerus cita-cita bangsa. Mereka memiliki peran strategis dalam menjamin eksistensi bangsa dan negara pada masa yang akan datang. Oleh karena itu, guna memikul tanggung jawab tersebut maka mereka perlu mendapatkan kebebasan untuk tumbuh dan berkembang dengan wajar.

Anak mempunyai posisi yang sangat strategis. Menurut Hariwijaya bahwa dalam keluarga, anak adalah prioritas utama sebagai tumpuan masa depan keluarga. Pada anak seluruh harapan dan cita-cita orang tua tertumpah. Namun seringkali hal ini menjadi beban berat yang harus dipikul oleh anak. Manakala orang tua menjadikan anak sebagai pelampiasan obsesi mereka yang belum tercapai. Anak dijadikan sarana untuk mengejawantahkan impian mereka. Sehingga hal ini menjadi tidak sehat bagi anak, mereka dipaksa berjalan menurut rel yang telah digariskan orang tua mereka tanpa bisa melawan (Kristianto, 2011: 44). 
Berdasarkan hal tersebut, begitu penting bagi kita untuk membenahi konsep sebuah pendidikan yang menyelenggarakan sistem belajar mengajar yang menghargai setiap potensi yang ada, serta di selaraskan dengan kondisi psikologi siswa, sehingga otak mereka akan sangat mudah untuk bekerja sama dalam proses pembelajaran dan proses belajar pun akan menjadi sangat optimal dan efektif.Siswa tidak hanya dikurung di dalam kelas, tetapi juga belajar di ruang terbuka dengan berbagai variasi model pembelajaran dan dikemas dalam aktivitas yang menantang dan permainan edukatif. Budaya belajar harus menjadi "Petualangan seumur hidup" dan "Perjalanan eksplorasi tanpa akhir", sehingga pertumbuhan seluruh kepribadian terintergrasi dengan nilai-nilai yang dipelajari. Dengan demikian "belajar" akan menjadi sangat bermakna dan mampu mencetak pribadi-pribadi yang berkualitas yang lebih dikenal dengan konsep pendidikan ramah anak yang selanjutnya akan disebut sekolah ramah anak.

Untuk mewujudkan hal tersebut, banyak hal yang harus dipenuhi di antaranya selalu mengajak anak berpartisipasi dalam memutuskan setiap kebijakan sekolah misalnya dalam hal penyusunan tata tertib sekolah atau jenis hukuman bila mereka melanggar. Selain itu, sarana dan prasarana yang ada di sekolahpun harus dipenuhi.Pendidik juga mempunyai peran yang sangat signifikan, mereka harus mampu menjadi pendidik yang ramah terhadap anak dan mampu menjadi fasilitator yang baik bagi anak didiknya. Sementara anakpun harus dinilai sikap dan perilakunya ketika mereka berinteraksi dengan temannya pada saat istirahat. Selain itu guru harus memberikan rasa aman dan keselamatan kepada setiap peserta didik di dalam menjalani masa-masa belajarnya. Hal ini dikarenakan sekolah hingga detik ini belum bisa menjadi tempat yang ramah bagi siswa.

Dengan demikian anak bukan lagi sebagai obyek dalam pendidikan namun sebagai subyek, anak bebas berkreasi dalam belajar dengan suasana lingkungan pendidikan yang penuh dengan kasih sayang. Tugas dan tanggung jawab guru di sekolah ataupun diluar sekolah sangat kental dengan pesan-pesan moral kebaikan. Karena itu, tidak salah jika dikatakan bahwa ketika seorang guru mengajarkan sesuatu di kelas, itu berarti sama dengan menyampaikan pesan-pesan Tuhan berupa kebajikan-kebajikan kepada siswa. 
Hal ini senada dengan yang diungkapkan oleh Moh.Suryo tentang peranan guru di sekolah, keluarga, dan masyarakat dipandang dari segi diri pribadinya, seorang guru harus berperan sebagai;(1) pekerja sosial; seorang yang harus memberikan pelayanan kepada masyarakat, (2) pelajar dan ilmuwan; seorang yang harus senantiasa belajar secara terus menerus untuk mengembangkan penguasaan keilmuan, (3) orang tua; guru adalah wakil orang tua peserta didik bagi setiap peserta didik di sekolah, (4) model keteladanan; guru merupakan model perilaku yang harus dicontoh oleh peserta didik di sekolah, (5) pemberi rasa aman dan kasih sayang bagi setiap peserta didik. Peserta didik diharapkan akan merasa aman berada dalam didikan gurunya (Rohinah M.Noor, 2012:123).

Hal itu selaras dengan UU No.23 tahun 2002 pasal 54 tentang Perlindungan anak yang berbunyi: "Anak di dalam dan di lingkungan sekolah wajib dilindungi dari tindakan kekerasan yang dilakukan oleh guru, pengelola sekolah atau temantemannya di dalam sekolah yang bersangkutan atau lembaga pendidikan lainnya." Dari pasal tersebut dapat ditarik kesimpulan dimana seorang anak harus merasa aman dan nyaman selama proses pembelajaran. Salah satunya dengan menciptakan lingkungan yang ramah anak, yaitu membuat suasana yang aman, nyaman, sehat dan kondusif, menerima anak apa adanya, dan menghargai potensi anak (Arismantoro, 2008:2).

Berkaitan dengan ramah anak pendidikan di Indonesia membutuhkan profil lembaga pendidikan yang dapat dijadikan contoh sebagai pendidikan ramah anak. Kota Surakarta merupakan salah satu kota yang termasuk dalam pengembangan kota layak anak. Terpilihnya Surakarta sebagai tuan rumah $2^{\text {nd }}$ International Conference on Child Friendly Asia Pacific karena pengembangan Kota Surakarta yang terbilang cukup memuaskan. Surakarta terpilih karena dinilai berhasil menjalankan program kota layak anak secara baik. Di antaranya telah menerbitkan pemeliharaan kesehatan anak, bantuan pendidikan anak, pengadaan taman cerdas, serta kartu insentif anak (Poskota, 2011).

SDIT Nur Hidayah Surakarta merupakan lembaga sekolah yang pertama kali mencanangkan diri sebagai sekolah yang mempelopori pendidikan ramah anak. Hal itu diwujudkan dengan berbagai indikator pendukung, seperti Visi \& Misi, 
program ektrakurikuler, pembinaan tenaga pendidik (guru) terkait pembelajaran, sarana bermain, minat bakat dan berbagai indikator pendukung lainnya.Untuk mencapai sekolah ramah anak ini juga tidak lepas dari kelengkapan sarana prasarana (sarpras) fisik di sekolah. Saat ini, SDIT Nur Hidayah telah memiliki sebanyak 45 fasilitas Mandi Cuci Kakus (MCK) bagi siswanya. Untuk sistem pembelajaran semua guru diharuskan memiliki kemampuan mengajar menyenangkan, yakni menggunakan sistem Pembelajaran Aktif, Inovatif, Kreatif, Efektif, dan Menyenangkan (PAIKEM). Hal itu dilakukan agar Kegiatan Belajar Mengajar (KBM) siswa tidak merasa bosan. Sehingga, dengan begitu pelajaran yang diajarkan dapat diterima dengan mudah oleh siswa. Untuk kelas satu dan dua menggunakan sistem pembelajaran thematic teaching, opening thematic dan diakhir pembelajaran selalu diadakan kegiatan di luar kelas (outing class).

Menurut Bashori Muchsin, dkk (2010:183) dari pola pendidikan ramah anak, akan terlahir anak-anak didik yang tidak hanya cerdas intelektualitasnya, tetapi juga cerdas nuraninya. Cerdas intelektualitas saja hanya membuat anak didik layaknya robot akibat selalu di jejali kurikulum, sehingga kecerdasan intelektualitasnya ini perlu diselaraskan dengan kebeningan nuraninya. Dari uraian di atas, penelitian ini mencoba untuk mengamati penerapan Pendidikan Ramah Anak yang dilaksanakan di Sekolah Islam Terpadu. Sehingga penelitian ini diberi judul: "Pendidikan Ramah Anak" (Studi Kasus SDIT Nur Hidayah Surakarta).

\section{Pendidikan Ramah Anak}

Menurut Arismantoro (2008) yang dimaksud dengan pendidikan ramah anak adalah menciptakan lingkungan belajar yang kondusif (condusive learning community) sehingga anak dapat belajar dengan efektif di dalam suasana yang memberikan rasa aman, penghargaan tanpa ancaman, dan memberikan semangat. Hal senada juga di ungkapkan oleh Ngadiyo (2013:18) bahwa pendidikan ramah anak adalah pendidikan yang anti diskriminatif, menerapkan PAIKEM, perhatian dan melindungi anak, lingkungan yang sehat, serta adanya partisipasi orang tua dan masyarakat. Disamping itu, sekolah ramah anak tidak menekan, memaksa, dan mengintimidasi anak sehingga anak memiliki kemerdekaan memilih belajar dan 
mengembangkan potensinya dengan senang dan riang. Hal tersebut sejalan dengan apa yang diungkapkan oleh Aqib bahwa model sekolah ramah anak lebih banyak memberikan prasangka baik kepada anak, guru menyadari tentang potensi yang berbeda dari semua peserta didiknya sehingga dalam memberikan kesempatan kepada siswanya dalam memilih kegiatan dan aktivitas bermain sesuai minatnya (Kristanto, 2011: 41).

Dari pengertian diatas dapat disimpulkan bahwa pendidikan ramah anak merupakan proses bagaimana seorang anak bisa bersemangat, antusias, dan berbahagia dalam mengikuti pelajaran dikelas, bukannya terbebani dan menjadikan belajar di sekolah sebagai momok yang menakutkan. Dengan begitu, mereka bisa mendapatkan pengetahuan dengan baik, mengikuti pembelajaran dengan nyaman dan aman.

Sedangkan menurut Bashori Muchsin (2010:182) menyatakan bahwa pola pendidikan berbasis ramah anak yaitu suatu bentuk penyelenggaraan pendidikan yang memperlakukan anak sebagai subyek yang hidup, punya hak berekspresi, hak menikmati kegembiraan, hak bermain, hak berkomunikasi inklusif, dan hak berdemokratisasi. Dalam hal ini pendidikan ramah anak itu tidak hanya terfokus pada penyelenggaraan proses pembelajaran yang menihilkan (menghilangkan) praktik radikalitas atau gaya represif terhadap anak didik, tetapi juga terhadap setiap kebijakan dari pengelola pendidikan yang membuatnya kehilangan hak-hak fitri atau fundamentalnya sebagai subjek pendidikan.

Hal tersebut sejalan dengan apa yang disampaikan Kristanto (2011:41) bahwa sekolah ramah anak adalah sebuah konsep sekolah yang terbuka, berusaha mengaplikasi pembelajaran yang meperhatikan perkembangan psikologis siswanya. Mengembangkan kebiasaan belajar sesuai dengan kondisi alami dan kejiwaan anak.

Berbeda halnya dengan Maria Ulfah (2010:64) menyatakan bahwa pendidikan ramah anak adalah pola pendidikan yang menggunakan perspektif gender, yaitu model pendidikan yang meniscayakan keadilan,baik laki-laki maupun perempuan. Artinya, penanaman nilai dalam proses pendidikan anak ditekankan pada pemahaman bahwa sifat-sifat feminisme dan sifat-sifat maskulin memiliki nilai yang sama pentingnya dalam kehidupan sosial. Pendidikan yang berkeadilan gender ini 
sebaiknya dimulai sejak anak-anak masih kecil,bahkan bayi. Hal ini berarti bahwa seorang anak dituntut untuk kritis dan tidak membedakan jenis kelamin. Pengertian disini lebih condong ke keadilan manusia yang berasakan gender dan hak asasi manusia.

Perbedaan pendapat yang dikemukakan oleh para pakar tersebut merupakan suatu hal yang wajar karena dipengaruhi oleh perbedaan latar belakang, baik dari pendidikan, sosiologis maupun sudut pandang yang digunakan oleh para pakar tersebut.Dari beberapa pengertian diatas maka pendidikan ramah anak ini dapat disimpulkan sebagai pendidikan yang mengedepankan lingkungan belajar yang ramah, aman, nyaman dan penuh kasih sayang yang sangat berpengaruh dalam perkembangan dan pembentukan karakter anak tanpa adanya diskriminasi.

\section{Ciri-ciri Pendidikan Ramah Anak}

Menurut Kristanto (2011:46-47) ada beberapa ciri-ciri Sekolah Ramah Anak yang ditinjau dari beberapa aspek:

1) Sikap terhadap murid. Perlakuan adil bagi murid laki-laki dan perempuan, cerdas-lemah, kaya-miskin, normal-cacat, anak pejabat-anak buruh, Penerapan norma agama, sosial dan budaya setempat. Serta Kasih sayang kepada murid, memberikan perhatian bagi mereka yang lemah dalam proses belajar karena memberikan hukuman fisik maupun nonfisik bisa menjadikan anak trauma. Saling menghormati hak-hak anak, baik antar murid, antar tenaga, kependidikan serta antara tenaga kependidikan dan murid.

Seorang pendidik harus menyadari bahwa setiap peserta didik mempunyai potensi yang kadang-kadang tidak dapat terungkap, tidak diterima, dan tidak dihargai dalam proses pendidikan. Oleh karena itu, seorang guru harus mengembangkan cara pandang yang positif terhadap siswa dan tidak boleh membeda-bedakan antara siswa satu dengan siswa yang satunya. Cara pandang yang positif akan mendorong guru untuk mengembangkan perilaku yang konstruktif, suportif, humanis, demokratis, dan tidak menggunakan cap negative atau perilaku-perilaku yang menghancurkan harga diri siswa.

| Volume. 1, No. 2, Juli-Desember 2016 
2) Metode Pembelajaran. Terjadi proses belajar sedemikian rupa sehingga siswa merasakan senang mengikuti pelajaran, tidak ada rasa takut, cemas dan waswas, siswa menjadi lebih aktif dan kreatif serta tidak merasa rendah diri karena bersaing dengan teman siswa lain. Terjadi proses belajar yang efektif yang dihasilkan oleh penerapan metode pembelajaran yang variatif dan inovatif.

Dalam proses pembelajaran seorang guru harus mampu mengorganisasi setiap kegiatan belajar- mengajar dan menghargai anak didiknya sebagai suatu subjek yang memiliki bekal dan kemampuan. Oleh karena itu, interaksi antara seorang guru dengan siswa harus lebih banyak berbentuk pemberian motivasi dari guru kepada siswa, agar siswa merasa senang, memiliki semangat, potensi dan kemampuan yang dapat meningkatkan harga dirinya. Dengan demikian siswa diharapkan dapat lebih aktif dalam melakukan kegiatan belajar.

3) Fasilitas Pembelajaran :Proses belajar mengajar didukung oleh media ajar seperti buku pelajaran dan alat bantu ajar/peraga sehingga membantu daya serap murid. Guru sebagai fasilitator menerapkan proses belajar mengajar yang kooperatif, interaktif, baik belajar secara individu maupun kelompok. Terjadi proses belajar yang partisipatif. Murid lebih aktif dalam proses belajar. Guru sebagai fasilitator proses belajar mendorong dan memfasilitasi murid dalam menemukan cara/ jawaban sendiri dalam suatu persoalan.

Suatu proses belajar-mengajar dikatakan baik, bila proses tersebut dapat membangkitkan kegiatan belajar yang efektif. Dalam tata kelola pembelajaran, guru tidak hanya memberi sejumlah teori, wawasan, dan pengalaman saja kepada siswa, karena boleh jadi ada siswa yang malas, tidak punya semangat, motivasinya rendah, dan tidak memiliki kepercayaan diri yang baik. Untuk itu, dalam proses pembelajaran guru harus mampu memerankan dirinya sebagai pelayan belajar. Selaku pelayan belajar, guru tidak mengartikan mengajar sebagai upaya mentransfer sejumlah ilmu pengetahuan, teori, maupun informasi semata kepada para peserta didik. Mengajar adalah proses membantu kesulitan belajar siswa dalam menemukan dan mengembangkan potensi dan jati dirinya secara utuh.

4) Pelibatan Murid:Murid dilibatkan dalam berbagai aktifitas yang mengembangkan kompetensi dengan menekankan proses belajar melalui 
berbuat sesuatu (learning by doing, demo, praktek, dan lain sebagainya).Melalui berbagai aktivitas dapat menjadi tempat yang menunjang bagi berbagai kegiatan dan kesempatan belajar bagi anak-anak. Hal ini karena dengan melakukan aktivitas dapat merangsang perkembangan serta pertumbuhan fisik dari seorang anak. Melalui kegiatan anak-anak dapat mengembangkan rasa percaya diri, menjadi lebih sosial, belajar mandiri, mengembangkan intelektualnya, dan belajar menyelesaikan permasalahan yang muncul.

5) Penataan Kelas; Murid dilibatkan dalam penataan bangku, dekorasi dan ilustrasi yang menggambarkan ilmu pengetahuan, dan lain sebagainya. Penataan bangku secara klasikal (berbaris ke belakang) mungkin akan membatasi kreatifitas murid dalam interaksi sosial dan kerja dikursi kelompok, Murid dilibatkan dalam menentukan warna dinding atau dekorasi dinding kelas sehingga murid menjadi betah di dalam kelas, Murid dilibatkan dalam memajang karya murid, hasil ulangan/ test, bahan ajar dan buku sehingga artistik dan menarik serta menyediakan space untuk baca (pojok baca). Bangku dan kursi sebaiknya ukurannya disesuaikan dengan ukuran postur anak Indonesia serta mudah untuk digeser guna menciptakan kelas yang dinamis.

Penataan ruang kelas yang baik, rapih, indah, terstruktur dan terintergrasi, akan lebih memudahkan guru dan anak dalam melakukan pembelajaran. Ruang kelas yang baik akan membuat anak semakin terdorong untuk aktif melakukan kegiatan yang dipilih oleh mereka sendiri. Penataan dan iklim yang baik juga akan membantu anak memahami hak dan perasaan dirinya serta hak dan perasaan orang lain. Dengan penataan yang baik anak akan lebih memahami aturan-aturan yang harus diikutinya tanpa harus mendengarkan penjelasan gurunya setiap hari.

6) Lingkungan Kelas; Murid dilibatkan dalam mengungkapkan gagasannya dalam menciptakan lingkungan sekolah (penentuan warna dinding kelas, hiasan, kotak saran, majalah dinding, taman kebun sekolah), tersedia fasilitas air bersih, higienis dan sanitasi, fasilitas kebersihan dan fasilitas kesehatan, fasilitas sanitasi seperti toilet, tempat cuci, disesuaikan dengan postur dan usia anak. Di sekolah diterapkan kebijakan/peraturan yang mendukung 
kebersihan dan kesehatan. Kebijakan/peraturan ini disepakati, dikontrol dan dilaksanakan oleh semua murid.

Lingkungan merupakan salah satu faktor penentu kunci keberhasilan dalam membangun kemampuan dan perilaku anak. Implikasinya adalah bahwa penyediaan lingkungan bagi anak hendaknya mendapat prioritas, apalagi jika lingkungan tersebut merupakan lingkungan belajar.

Sedangkan menurut Chabib Mustafa (2009) sebuah kawasan bisa dimasukan dalam kategori ramah anak apabila memiliki ciri-ciri sebagai berikut:

1) Anak terlibat dalam pengambilan keputusan tentang masa depan diri, keluarga, dan lingkungannya. Pemberian kesempatan yang terbuka misalkan dalam pengambilan keputusan tentang masa depan diri, keluarga, dan lingkunganya disertai dengan kepercayaan terhadap kemampuan anak merupakan sikap para guru yang sangat diharapkan. Tanpa sikap ini, perlengkapan sehebat apa pun yang disediakan disekolah tidak akan optimal dalam membantu perkembangan anak. Guru harus yakin pada kemampuan anak. Keyakinan dan kepercayaan ini akan membuat sikapnya memberikan keleluasaan dan menempatkan anak sebagai subjek dan center pembelajaran. Dengan kepercayaan dan kesempatan yang diberikan, anak pun akan terbantu untuk percaya pada diri dan kemampuannya, ia tidak akan ragu untuk mencoba dan mewujudkan keinginannya untuk bereksplorasi dan mengembangkan potensinya.

2) Kemudahan mendapatkan layanan dasar pendidikan, kesehatan dan layanan lain untuk tumbuh kembang.Pendidikan merupakan proses yang sangat penting bagi umat manusia. Melalui pendidikan inilah setiap orang belajar selurih hal yang belum diketahui. Melalui pendidikan akan lahir seorang yang berilmu. Sama halnya dengan kesehatan yang sangat penting untuk keberlangsungan hidup manusia. Dalam kaitanya dengan pengembangan kawasan ramah anak, maka seorang anak itu harus mendapatkan suatu pelayanan pendidikan dan kesehatan dengan mudah. Karena anak merupakan generasi yang meneruskan keberlangsungan kehidupan ini. 
3) Adanya ruang terbuka untuk anak dapat berkumpul, bermain, dan berkreasi dengan sejawatnya dengan aman serta nyaman.Keamanan dan kenyaman merupakan hal yang harus diperhatikan oleh pihak sekolah. Hal ini dilakukan untuk mengantisipasi kecelakaan yang dapat terjadi kapan saja, dan dimana saja, mengingat usia anak yang masih belum matang secara fisik dan mental dalam merencanakan dan mempergunakan tubuhnya.

4) Adanya aturan yang melindungi anak dari bentuk kekerasan dan eksploitasi.Kasus kekerasan yang sering terjadi saat ini harus menjadi perhatian penuh dalam dunia pendidikan. Hal ini dikarenakan, kasus kekerasan yang terjadi rata-rata pada usia anak-anak sekolah dasar, baik kekerasan seksual atau dikriminasi. Oleh karena itu, pihak sekolah harus benar-benar memperhatikan dan melindungi anak dari segala bentuk kekerasan dengan membuat peraturan serta kebijakan-kebijakan yang mendukung perlindungan anak.

5) Tidak adanya diskriminasi dalam hal apapun terkait suku, ras, agama, dan golongan.Sikap diskriminasi selayaknya tidak boleh terjadi dalam menciptakan kawasan ramah anak. Indonesia terdiri dari berbagai macam suku, ras, agama, dan berbagai golongan. Oleh karena itu, perlu adanya penanaman sikap saling menghormati dan menghargai satu sama lain yang tentunya dimulai dari seorang anak-anak. Hal ini dapat dilakukan dalam kegiatan pembelajaran dan kehidupan sehari-hari.

Dari ciri-ciri pendidikan ramah anak di atas dapat disimpulkan bahwa suatu pendidikan dapat dikatakan ramah anak apabila dengan melihat kondisi lingkungan belajar yang aman, nyaman, dan penuh kasih sayang sebab hubungan yang terjalin dengan rasa cinta dan kasih sayang antara anak dengan guru, orang tua, maupun sesama teman sebanyanya sangat berpengaruh dalam membentuk karakter seorang anak.

\section{Syarat Pendidikan Ramah Anak}

Terdapat beberapa persyaratan yang harus dilakukan dalam menerapkan pola pendidikan yang ramah terhadap anak. Sebagaimana menurut Maria Ulfah (2010:6572), syarat pendidikan ramah anak tersebut antara lain: 
1) Tidak membedakan jenis kelamin. Orang tua hendaknya tidak membedabedakan dalam memperlakukan anak laki-laki dengan perempuan. Mulailah dengan hal kecil,misalnya pilihan warna,mainan dan sebagainya. Setelah anak mulai mengenal lingkungannya,berikan kebebasan kepada anak laki-laki dan perempuan untuk tumbuh dan mengekspresikan keingintahuannya. Selain memulai dari keluarga, di sekolah juga guru-guru hendaknya menerapkan kurikulum dan perlakuan terhadap anak didik secara setara. Begitu juga didalam masyarakat,harus diciptakan struktur yang menghargai semua peran laki-laki dan perempuan adalah sama.Model pendidikan dengan menanamkan nilai-nilai adil gender ini harus diberikan kepada anak secara terpadu, baik di dalam keluarga,sekolah,maupun dilingkungan masyarakat.

2) Menumbuhkan sikap kritis kepada anak.Pendidikan kritis untuk anak dapat juga diartikan bahwa anak dapat menanyakan apa saja yang ingin diketahuinya tanpa merasa takut dan ragu, dan orang tua, guru atau yang ditanya harus mampu menjawab seluruh pertanyaan anak secara tepat dan benar.

3) Tidak diskriminatif dan menghargai perbedaan. Anak sejak dini diperkenalkan pada nilai-nilai yang menghargai perbedaan. Perbedaan tidak perlu dipertentangkan, akan tetapi harus ditumbuhkan sikap saling menghargai satu sama lain.

4) Demokratis.Pendidikan demokratis dapat diberikan kepada anak usia dini dengan memberikan kesempatan kepada anak untuk membuat pilihan-pilihan yang disukainya dari hal-hal yang paling sederhana. Misalnya, memilih warna mainan,makanan yang disuka.

Dari syarat-syarat pendidikan ramah anak di atas dapat disimpulkan bahwa pendidikan ramah anak ini merupakan pendidikan yang mengedepankan potensi anak untuk lebih bersikap kritis,demokratis,dan tidak diskriminatif.Sekolah sebagai lembaga pendidikan formal merupakan sebuah tempat dimana para orang tua menyerahkan anak-anak mereka untuk mencari ilmu pengetahuan dan memperbaiki perilaku mereka.Di sekolah, para siswa datang untuk belajar guna meraih cita-cita dan juga masa depan yang lebih baik. Akan tetapi, sekolah hingga saat ini belum bisa menjadi tempat yang ramah untuk anak. Hal ini dikarenakan sering kali terjadinya 
kasus kekerasan atau tindak kekerasan di sekolah baik itu dilakukan oleh guru atau sesama siswa itu sendiri.

Dalam hal ini peran pendidik harus signifikan, mereka harus mampu menjadi pendidik yang ramah terhadap anak dan mampu menjadi fasilitator yang baik bagi anak didiknya.Sementara siswapun harus dinilai sikap dan perilakunya ketika mereka beinteraksi dengan temannya.Dengan demikian anak bukan sebagai obyek dalam pendidikan namun sebagai subyek, sehingga anak bebas berkreasi dalam belajar dengan suasana lingkungan pendidikan yang penuh dengan kasih sayang.Dengan pola pendidikan ramah anak maka akan terlahir anak-anak didik yang tidak hanya cerdas intelektualitasnya, tetapi juga cerdas nuraninya.

\section{Pembahasan}

Hasil penelitian menunjukan bahwa SDIT Nur Hidayah Surakarta merupakan lembaga sekolah yang mencanangkan diri sebagai lembaga pendidikan yang ramah anak. Hal itu diwujudkan dengan berbagai indikator pendukung, seperti dari pemaparan Visi dan Misi sekolah, sarana dan prasarana yang mendukung, program ekstrakurikuler, pembinaan tenaga pendidik (guru) terkait pembelajaran, sarana bermain, minat bakat dan berbagai indicator yang lainnya.

Selain itu berkaitan dengan konsep penerapan pendidikan ramah anak di SDIT Nur Hidayah Surakarta dapat diklasifikasikan menjadi 4 yaitu pendidikan ramah anak dilihat dari:

1) Ramah Fisik; dilihat dari bangunan sekolah atau kondisi lingkungan, dimana SDIT Nur Hidayah Surakarta di bangun di atas tanah \pm 2500 , yang terdiri dari $1750 \mathrm{~m}^{2}$ yang sudah dimanfaatkan. SDIT Nur Hidayah Surakarta berada di tengah-tengah perumahan penduduk, tetapi tetap terjangkau. Lokasi, situasi dan kondisi SDIT Nur Hidayah sungguh kondusif, untuk proses pembelajaran karena tidak banyak kendaraan yang melintas dan ketika ada yang melintas pun kecepatan tidak boleh lebih dari $10 \mathrm{~km} / \mathrm{jam}$ terlihat dari tanda markas yang berada di utara sekolah.

Gedung SDIT Nur Hidayah terbagi menjadi dua gedung yakni gedung yang berada di sebelah barat dan timur jalan. Gedung yang berada di timur jalan terdiri 
dari 3 lantai. Di lantai pertama terdiri dari pos satpam, ruang TU, ruang kepala sekolah, aula, UKS, ruang kepala sekolah, aula, UKS, tempat wudhu dan ruang perlengkapan olahraga. Di lantai kedua terdiri dari masjid untuk putra ruang kelas 5 dan 6 yang sebagian juga berada di lantai 3 dan juga masjid untuk putri juga berada di lantai 3. Gedung yang berada di sebelah barat terdiri 3 lantai yang terdapat koperasi, kantin, lapangan basket, dan ruang kelas 1 sampai kelas 4 .

2) Ramah Non Fisik; terkait dengan pertimbangan rasa aman, pertimbangan minat dan rasa ingin tahu anak, pertimbangan kebebasan berekspresi, pertimbangan membangun percaya diri dan aktualisasi diri, pertimbangan menyalurkan emosi, serta pertimbangan kegembiraan dan kesenangan anak.

SDIT Nur Hidayah setiap hari sabtu merupakan hari bebas dari kegiatan belajar mengajar di dalam kelas. Anak-anak diberi kegiatan untuk mengembangkan minat dan bakatnya. Misalnya, belajar memasak nasi goreng, melukis, membuat majalah dinding dan lain sebagainya. SDIT Nur Hidayah juga melaksanakan kegiatan ekstrakurikuler yang dilaksanakan di luar jam regular kurikuler. Kegiatan ini sebagai kegiatan untuk pengembangan diri.Kegiatan ekstrakurikuler sendiri diampu oleh guru dan orang dibidang ahlinya.Hal ini dilakukan untuk memberikan kepada siswa kebebasan mengembangkan minat dan bakat mereka. Selain kegiatan ekstrakurikuler ada juga kegiatan pengembangan kompetensi siswa yaitu melalui kegiatan outing class. Murid dilibatkan dalam berbagai aktivitas yang mengembangkan kompetensi dengan menekankan proses belajar melalui berbuat sesuatu.

3) Kegiatan Pembelajaran di dalam kelas (Internal Learning Class); Program pendidikan ramah anak di SDIT Nur Hidayah dilihat dari segi prosespembelajaran di dalam kelas menggunakan pendekatan pembelajaran aktif, inovatif, kreatif, menyenangkan,sehingga memudahkan siswa dalam mencapai kompetensi yang ditargetkan serta didukung kegiatan ekstrakurikuler yang mengarah pada life skill. Selain itu menerapkan aspek quantum teaching dai quantum learning serta pembelajaran berbasis Students Active Learning (SAL) dan Contextual Teaching and Learning (CTL). 
4) Kegiatan Pembelajaran di luar kelas (external learning class); SDIT Nur Hidayah Surakarta didesain seperti sekolah pada umumnya akan tetapi, tetap menyesuaikan dengan dunia anak-anak. Ada taman bermain, aula untuk kegiatan siswa serta ada kantin, koperasi, lapangan dan lain sebagainya. Selain itu, untuk menumbuhkan keharmonisan antar warga sekolah SDIT Nur Hidayah Surakarta juga membangun pola komunikasi yang baik, antara siswa dengan guru, siswa dengan karyawan, dan guru dengan karyawan. Missal ketika ada seorang siswa yang meminta tolong baik kepada guru, pegawai harus dilayani dengan sepenuh hati tidak boleh membeda-bedakan. Sehingga siswa merasa nyaman dan tidak ada rasa takut sedikitpun karena pola interaksi yang dibangun dengan menggunakan pola kekeluargaan. Tidak hanya itu saja pola komunikasi antara pihak sekolah dengan wali murid juga dibangun. Hal ini dengan adanya program Paguyuban Orang Tua Murid dan Guru (POMG).

\section{Kesimpulan}

Berdasarkan hasil penelitian yang dilakukan di SDIT Nur Hidayah Surakarta mengenai pendidikan ramah anak dapat diambil kesimpulan bahwa Pendidikan ramah anak dimana sekolah tersebut dapat menciptakan lingkungan yang ramah anak, yaitu membuat suasana yang aman, nyaman, sehat dan kondusif, menerima anak apa adanya, dan menghargai potensi anak.Dengan demikian anak bukan lagi sebagai obyek dalam pendidikan namun sebagai subyek, anak bebas berkreasi dalam belajar dengan suasana lingkungan pendidikan yang penuh dengan kasih sayang. Berkaitan dengan hal tersebut, pendidikan ramah anak di SDIT Nur Hidayah Surakarta meliputi; Ramah Fisik, Ramah Non Fisik, Kegiatan Pembelajaran di dalam kelas, dan Kegiatan Pembelajaran di luar kelas. 


\section{Daftar Pustaka}

Abdul Rahman Assegaf.2004. Pendidikan Tanpa Kekerasan. Jogjakarta: Tiara Wacana.

Abdullah Nashih Ulwan.1993. Pedoman Pendidikan Anak Dalam Islam jilid satu. Semarang: CV AsySyifa.

Abdullah Nashih Ulwan.1994. Pendidikan Anak Dalam Islam edisi 2.Jakarta:Pustaka Amani.

Ahmad Barizi (ed.). 2005. Holistik Pemikiran Pendidikan A. Malik Fadjar Jakarta: Raja Grafindo Persada.

Ahmad Sutanto.2013.Teori Belajar \& Pembelajaran di Sekolah Dasar.Jakarta:Prenada Media Group.

Ari Wibowo. 2014. Penerapan Regresi Logistik Ordinal untuk Pemodelan Faktorfaktor Yang mempengaruhi tingkat kesiapan mahasiswa jurusan PAI tahun pertama mengikuti kelas Bilingual. Hasil penelitian Kompetitif Berkelanjutan Berbasis Pengembangan Lembaga. Pusat Penelitian dan Penerbitan LP2M IAIN Surakarta.

Arismantoro.2008. Character Building: Bagaimana MendidikAnak Berkarakter.Yogyakarta: Tiara Wacana.

Barbara Coloroso. 2007. Stop Bullying. Jakarta: PT IkrarMandiriabadi.

Bashori Muchsin,dkk.2010. Pendidikan Islam Humanistik: Alternatif Pendidikan Pembebasan Anak. Bandung:RefikaAditama.

Borg, W.R. \& Gall, M.D. 1983. Educational research: An intruduction. New York \& London: Longman. Book Company.

Darmaningtyas .2004.Pendidikan yang memiskinkan.Yogyakarta :Galang Press.

Dedi Mulyasana.2011.Pendidikan Bermutu dan Berdaya Saing.Bandung : Rosdakarya.

Depag RI. 1985. Pedoman Pembinaan Pondok Pesantren. Jakarta: Depag.

Departemen Pendidikan Nasional. 2007. Undang-Undang nomor 55 tahun 2007 tentang pendidikan agama dan keagamaan. Jakarta: Depdiknas.

Depdiknas.2003.Undang-undang Republik Indonesia Nomor 20 Tahun 2003 tentang sistem pendidikan nasional. Jakarta:Pusat Data dan Informasi Pendidikan 
Eveline Siregar \& Hartini Nara.2010.Teori Belajar \& Pembelajaran.Bogor:Ghalia Indonesia.

Gavin Reid. 2007.Memotivasi siswa di kelas Gagasan dan Strategi.Jakarta: Indeks.

Haryanto Al-Fandi.2011.Desain Pembelajaran yang Demokratis dan Humanis. Jogjakarta: Ar-Ruzz Media.

http://megapolitan.kompas.com/read/2013/12/21/0818161/1.620.Anak.Jadi.Korban. Kekerasan.Seksual.di.2013

http://poskota.co.id/berita-terkini/2011/06/29/solo-tuan-rumah-konperensi-kotalayak-anak

Ibrahim Amini.2006.Agar tak salah mendidik. Jakarta: Al-Huda.

John Holt.2012.Bagaimana Siswa Belajar.Jakarta: PTGelora Aksara Pratama.

Kristanto, Ismatul Khasanah dan Mila Karmila.2011.Identifikasi model sekolahramahanak (sra) jenjangsatuanpendidikananakusiadini se-kecamatan Semarang selatan.JurnalPenelitian PAUDIA, Volume 1 No. 1.ejurnal.ikippgrismg.ac.id .

Kunandar.2011.Guru Profesional Implementasi Kurikulum Tingkat Satuan Pendidikan (KTSP) dan Sukses dalam Sertifikasi Guru.Jakarta:Rajawali Press.

Lexy J. Moleong.2011. Metodologi Penelitian Kualitatif. Bandung: PT.Remaja Rosdakarya.

M. Sastrapratedja. 2003. Pembangunan Pendidikan Berwawasan Kemanusiaan., Dalam Masa depan kemanusiaan. Yogyakarta: Jendela,

Maria Ulfah Anshor\& Abdullah Ghalib. 2010. Parenting With Love. PanduanIslami mendidikanak penuhcinta dan kasih sayang.Bandung : PT MizanPustaka.

Meicky Shoreamanis Panggabean.2013.Menjadi Guru Itu Mengasyikkan!.Jakarta : Indeks.

Milles,Mathew B and Huberman, A.Michail.1992.Analisis Data Kualitatif.Jakarta: Universitas Indonesia.

Moh.Sholeh Hamid. 2011.Metode Edutainment. Jogjakarta: Diva Press.

Muhammad Nur Abdul Hafizh Suwaid. 2009. Prophetic Parenting Cara Nabi Mendidik Anak Jogjakarta : Pro-U Media.

| Volume. 1, No. 2, Juli-Desember 2016 
Munif Chatib.2011.Gurunya Manusia .Bandung: PT Mizan Pustaka.

Munif Chatib.2012.Orang tuanya Manusia.Badung: PT Mizan Pustaka.

Munif Chatib.2012.Sekolahnya Manusia.Bandung: PT Mizan Pustaka.

Munif Chatib \& Alamsyah Said. 2012. Sekolah anak-anak juara.Bandung: PT Mizan Pustaka.

Nawabudin. Abdurrab. 2005. Teknik Menghafal Al-Qur'an. Bandung : Sinar Baru.

Newell, Peter. 2005. The Human Rights Imperative for Ending All Corporal Punishment of Children. Eliminating Corporal Punishment: The Way Forward to Constructive Child Discipline. Paris: UNESCO Publishing.

Ngadiyo. 2013.”Homeschooling, Melejitkan Potensi Anak." Majalah Embun, Edisi 49-V-Rajab 1434.Mei 2013, hlm 18.

Ngainum Naim dan Achmad Sauqi.2010. Pendidikan Multikultural Konsep dan Aplikasi. Jogjakarta: Ar-Ruzz Media.

Norman K.Denzin \& Yvonna S.Lincoln. 2009. Handbook of Qualilative Research. Yogyakarta: PustakaPelajar.

NovanArdy Wiyani. 2012. Save Our Children from School Bullying. Jogjakarta: ArRuzz Media.

Rohinah M.Noor.2012.Mengembangkan Karakter Anak Secara Efektif di Sekolah dan di Rumah. Yogyakarta : Pedagogia.

Sa'dulloh. 2008. 9 Cara Praktis Menghafal Alqur'an. Jakarta: Gema Insani.

Salim, Ahmad. 2011. Hukum Fiqih Seputar Alqur'an. Jakarta: Ummul Qura.

Sardiman A.M.2012.Interaksi \& Motivasi Belajar Mengajar.Jakarta: PT Raja Grafindo Persada.

Taylor, Insup. 1990. Psycholinguistiks: Learning and Using Language. Englewood Cliffts: Prentice-Hall.Inc

Ummu Shofi. 2007. AgarCahaya Mata Makin Bersinar. Surakarta: Indiva.

UU No.23 Tahun 2002 Tentang Perlindungan Anak. 2010. Bandung: Refika Aditama.

W.J.S. Poerdarminta. 1985.Kamus Umum Bahasa Indonesia. Jakarta: Balai Pustaka. 